\title{
New Bis(imino)pyridine Complexes of Iron(II) and Iron(III), and Their Catalytic Activity in the Mukaiyama Aldol Reaction
}

\author{
Pushkar Shejwalkar, ${ }^{a}$ Nigam P. Rath, ${ }^{\text {a,b }}$ Eike B. Bauer*a \\ a University of Missouri-St. Louis, Department of Chemistry and Biochemistry, One University Boulevard, St. Louis, MO 63121, USA \\ Fax+1(314)5165342; E-mail: bauere@umsl.edu \\ b Center for Nanoscience, University of Missouri-St. Louis, St. Louis, MO 63121, USA \\ Received: 02.08.2013; Accepted after revision: 10.10.2013
}

\begin{abstract}
New iron(II) and iron(III) complexes bearing bis(imino)pyridine ligands were synthesized and successfully applied to the Mukaiyama aldol reaction. The two complexes $\left[\mathrm{FeCl}_{2} \mathbf{L}\right]$ ( $\mathbf{L}=$ bis(imino)pyridine ligand, $55 \%$ isolated yield) and $\left[\mathbf{L F e}(\mu \mathrm{Cl})_{3} \mathrm{FeCl}_{3}\right](76 \%)$ were obtained employing $\mathrm{FeCl}_{2}$ and $\mathrm{FeCl}_{3}$ iron sources, respectively, and characterized by elemental analyses, mass spectrometry, IR spectroscopy and, one example, by X-ray diffraction. The two new iron complexes were subsequently employed as catalysts in the Mukaiyama aldol reaction after abstraction of two chlorides by $\mathrm{AgSbF}_{6}$ to obtain the aldol products in $43 \%$ to virtually quantitative yield $\left(\mathrm{CH}_{2} \mathrm{Cl}_{2}\right.$ solvent, room temperature, 3.5 to $16 \mathrm{~h}$ reaction time). The impact of the oxidation state of the iron center on the reaction rate and the diastereomeric ratios of the products was investigated.
\end{abstract}

Key words: aldol reaction, catalysis, homogeneous catalysis, iron, ligands, nucleophilic addition

The Mukaiyama aldol reaction is a carbon-carbon bondforming reaction between silyl enol ethers $\mathbf{1}$ or silyl ketene acetals and carbonyl groups (as in 2) to give $\beta$-hydroxy ketones 4 and $\beta$-hydroxy esters, or their silylprotected derivatives 3 (Scheme 1). ${ }^{1}$ First reported by Mukaiyama and co-workers in $1973,{ }^{2}$ the reaction is frequently applied in the synthesis of complex organic molecules and natural products. ${ }^{3}$ The Mukaiyama aldol reaction is catalyzed by Brønsted ${ }^{4}$ or Lewis acids ${ }^{5}$ based on metals such as $\mathrm{Zr},{ }^{6} \mathrm{Bi},{ }^{7} \mathrm{~B},{ }^{8} \mathrm{Ti},{ }^{9} \mathrm{Pt}^{10}{ }^{10} \mathrm{Re},{ }^{11} \mathrm{Li},{ }^{12} \mathrm{In},{ }^{13}$ $\mathrm{Sc}^{14}$ and $\mathrm{Zn},{ }^{15}$ and by Lewis bases. ${ }^{16}$ Organocatalytic versions are known as well. ${ }^{1 a, 17}$ Depending on the silyl enol ether substrate employed, one or two new stereocenters are created in the product. Substituted enol ethers $\left(\mathrm{R}^{1} \neq \mathrm{H}\right.$ in Scheme 1) produce two new stereocenters, and give rise to the formation of syn- and anti-diastereomers. Obtaining high diastereomeric ratios and enantiomeric excesses is a goal of current research concerning the Mukaiyama aldol reaction. ${ }^{4 a}, 18$ Mechanistic investigations have revealed that the reactions proceed through an open transition state, ${ }^{19}$ and Newman projections of the transition state allow for the prediction of the diastereoselectivity of the reaction. ${ }^{20}$ The Lewis acid catalyst coordinates to the oxygen of the carbonyl group, making the carbon atom more susceptible to an attack by the silyl enol ether nucleophile.

SYNTHESIS 2014, 46, 0057-0066

Advanced online publication: 21.11.2013

DOI: 10.1055/s-0033-1340081; Art ID: SS-2013-M0541-OP

(c) Georg Thieme Verlag Stuttgart · New York

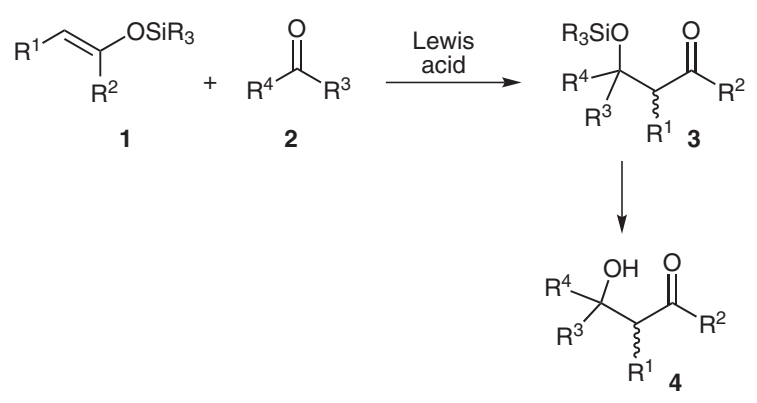

Scheme 1 The Mukaiyama aldol reaction

Accordingly, strong Lewis acids are among the most commonly employed catalysts for the reaction. In the original work, Mukaiyama and co-workers utilized freshly distilled, oxophilic $\mathrm{TiCl}_{4}$ and employed it in an equimolar amount. ${ }^{2}$ This reagent promotes the reaction between cyclic silyl enol ethers and both aldehydes and ketones. Somewhat weaker Lewis or Brønsted acids typically require aldehydes instead of ketones as coupling partners. ${ }^{15}$ Silyl enol ethers frequently employed (and also utilized in our study) include the cyclic enol ether $\mathbf{5}$, the enol ether $\mathbf{6}$ derived from acetophenone, and the commercial silyl ketene acetal 1-(tert-butyldimethylsiloxy)-1-methoxyethene (7, Figure 1). For steric and electronic reasons, these enol ether substrates exhibit a range of nucleophilicities. By analogy to Mayr's nucleophilicity scale, ${ }^{21} \mathbf{5}$ exhibits the lowest nucleophilicity, followed by $\mathbf{6}$; the silyl ketene acetal 7 exhibits the highest nucleophilicity among these three substrates. According to Mayr, the influences of steric effects on the nucleophilicities of comparable silyl enol ethers are more difficult to assess. We think that 7 is more nucleophilic than $\mathbf{6}$ due to electronic reasons. The challenge is to develop catalyst systems that are capable of coupling less reactive nucleophiles such as 5 with both aldehyde and ketone carbonyl groups. A balance needs to be found between an efficient, yet easy-to-handle and bench-stable, catalyst system that does not require the strict exclusion of moisture or air. Accordingly, a number of catalyst systems that can be employed under aqueous conditions have been reported. ${ }^{22}$

Iron complexes have also been employed as catalysts in the Mukaiyama aldol reaction, ${ }^{23}$ and enantioselective versions thereof have been reported as well. ${ }^{24}$ Iron catalysis has lately emerged as an intensely studied research area. ${ }^{25}$ 


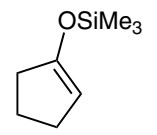

5

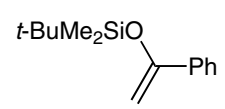

6
$t-\mathrm{BuMe}_{2} \mathrm{SiO}$ If $\mathrm{OMe}$
Figure 1 Silyl enol ether substrates

Iron catalysts have a number of advantages over other transition metals typically employed in catalysis. Iron is inexpensive, abundant, relatively nontoxic and environmentally friendly. Consequently, iron-based complexes have increasingly been investigated as catalysts in a number of organic transformations, such as in $\mathrm{C}-\mathrm{C},{ }^{26} \mathrm{C}-\mathrm{N},{ }^{27}$ $\mathrm{C}-\mathrm{P},{ }^{28} \mathrm{C}-\mathrm{B}^{29}$ and $\mathrm{C}-\mathrm{Si}^{30}$ bond-forming reactions, heteroatom-heteroatom bond-forming reactions, ${ }^{31}$ reductions, ${ }^{32}$ oxidations ${ }^{33}$ and polymerizations, ${ }^{34}$ as well as other functional group interconversions. ${ }^{35}$

However, iron-based catalyst systems for the Mukaiyama aldol reaction are still scarce. Mainly iron(II) complexes have been employed; we are aware of only one report where an iron(III) salt $\left(\mathrm{FeCl}_{3}\right.$ in combination with a surfactant under aqueous conditions) was utilized for catalysis. ${ }^{36}$ In all these reports, a variety of silyl enol ethers (such as those shown in Figure 1) were employed as the nucleophiles, but the carbonyl coupling partners were, in all cases, aldehydes. We hypothesized that a very strong Lewis acid is more efficient when demanding silyl enol ethers such as $\mathbf{5}$ are employed. We were, thus, interested in determining whether a preformed iron(III) complex is a suitable catalyst for the Mukaiyama aldol reaction and how it performs compared to a related iron(II) complex. According to the mechanistic understanding outlined above, a higher formal charge on the Lewis acid should improve its efficiency as a catalyst.

Accordingly, we describe herein the synthesis and characterization of bis(imino)pyridine complexes of iron(II) and iron(III). The bis(imino)pyridine ligand class is known ${ }^{37}$ and has previously been employed in the synthesis of iron complexes. ${ }^{38}$ Iron complexes of bis(imino)pyridines are widely utilized as ethylene polymerization catalysts, ${ }^{39}$ and also have been used to catalyze cyclization or cycloisomerization reactions; ${ }^{40}$ however, they have not been employed in the Mukaiyama aldol reaction to date.

We hypothesized that a bulky, tridentate ligand such as the bis(imino)pyridine ligand class might keep its corresponding iron complexes soluble even in relatively nonpolar solvents and might prevent the formation of dimers and oligomers as often observed for iron complexes with chloro or other potentially bridging ligands. ${ }^{41}$ After synthesis and characterization of the iron(II) and iron(III) complexes, we successfully employed them as catalysts in the Mukaiyama aldol reaction. Furthermore, we investigated the impact of the formal charge on the iron catalyst on the efficiency and diastereoselectivity of the reaction.

\section{Synthesis and Characterization of the Iron Complexes}

We selected specifically the known ${ }^{42}$ bis(imino)pyridine ligand $\mathbf{8}$ (Scheme 2) for the synthesis of the corresponding iron complexes. Ligand 8 can be synthesized by condensation of 1,6-diacetylpyridine with 2,6-diethylaniline in ethanol in the presence of a catalytic amount of glacial acetic acid. ${ }^{43}$ We also considered bis(imino)pyridine ligands with isopropyl substituents in the $2^{\prime}, 6^{\prime}$-positions, but encountered difficulties with converting these into the corresponding iron complexes.

Next, we targeted the synthesis of iron(II) and iron(III) complexes of ligand $\mathbf{8}$. We have previously synthesized iron complexes of the general formula $\left[\mathrm{FeL}_{2}(\mathrm{OTf})_{2}\right]$, where $\mathbf{L}$ is a phosphinooxazoline ligand and OTf is the weakly coordinating $\mathrm{F}_{3} \mathrm{CSO}_{3}{ }^{-}$counterion; ${ }^{44}$ however, the complex $\left[\mathrm{Fe}(\mathbf{8})(\mathrm{OTf})_{2}\right]$, when synthesized from $\left[\mathrm{Fe}(\mathrm{OTf})_{2}\right]$ and ligand $\mathbf{8}$, only showed at best moderate catalytic activity in the Mukaiyama aldol reaction. We, thus, changed to $\mathrm{FeCl}_{2}$ and $\mathrm{FeCl}_{3}$ as the iron source.

Accordingly, the ligand $\mathbf{8}$ and $\mathrm{FeCl}_{2}$ in $n$-butanol were heated for 15 minutes, as previously reported for related syntheses (Scheme 2). ${ }^{45}$ The complex $\left[\mathrm{FeCl}_{2} 8\right]$ was isolated as a dark blue solid in $55 \%$ yield by concentrating the solution and precipitation of the product complex by the addition of pentane. The complex was analyzed by IR and UV-vis spectroscopy, mass spectrometry and elemental analysis. Due to the paramagnetic nature of the new complex, characterization by NMR spectroscopy was not attempted.

The coordination of the ligand to the iron center was best seen by a shift of the $v_{\mathrm{C}=\mathrm{N}}$ stretching frequency in the IR spectrum. The free ligand $\mathbf{8}$ showed an imine $\mathrm{C}=\mathrm{N}$ stretch of $1639 \mathrm{~cm}^{-1}$, whereas the coordinated $\mathrm{C}=\mathrm{N}$ unit in the product showed a stretch at $1585 \mathrm{~cm}^{-1}$. Such a change of the imine stretching frequency upon coordination to an iron center has previously been observed by us ${ }^{46 a}$ and others. ${ }^{46 \mathrm{~b}}$ The UV-vis spectrum of complex $\left[\mathrm{FeCl}_{2} 8\right]$ exhibited a strong absorption at $698 \mathrm{~nm}$ and, due to its large molar absorption coefficient $\varepsilon$ of $1164 \mathrm{~cm}^{-1} \cdot \mathrm{M}^{-1}$, was tentatively assigned to a metal-to-ligand charge transfer (MLCT). Such absorptions have been previously reported for related iron complexes by us ${ }^{46 a}$ and others. ${ }^{47}$ The mass spectrum gave a molecular ion peak $\left[\mathrm{FeCl}_{2} \mathbf{8}\right]^{+}$with $m / z=551$, confirming the mononuclear nature of the complex and the coordination of the ligand. A fragment $[\mathrm{FeCl8}]^{+}$with $m / z=516$ was also observed in the FABMS. The elemental analysis for the complex was slightly low on carbon (presumably due to $\mathrm{FeCl}_{2}$ impurities) but still confirmed the overall molecular formula $\left[\mathrm{FeCl}_{2} 8\right]$. The analysis of the complex by X-ray diffraction is described below.

Similarly, we also treated the ligand $\mathbf{8}$ with $\mathrm{FeCl}_{3}$ (Scheme 2). When a solution of $\mathrm{FeCl}_{3}$ in diethyl ether was added to a solution of the ligand $\mathbf{8}$ in diethyl ether, an orange-red solid precipitated immediately. The mother liquor was decanted and the solid precipitate was washed several times 
with diethyl ether to obtain the product as an orange-red solid. The ether washings were slightly yellow in color; analysis of the combined ether portions used for washing revealed that half of the ligand $\mathbf{8}$ had not reacted with the $\mathrm{FeCl}_{3}$; on the other hand, there was no evidence for unreacted $\mathrm{FeCl}_{3}$ starting material, as judged from the color of the washings and the precipitate. Based on instrumental analysis, as detailed below, we came to the conclusion that the isolated material had a dimeric structure best described as $\left[8 \mathrm{Fe}(\mu \mathrm{Cl})_{3} \mathrm{FeCl}_{3}\right]$, and was isolated in $76 \%$ yield.

Again, the coordination of the ligand to the iron center was best seen by a shift of the $v_{\mathrm{C}=\mathrm{N}}$ stretching frequency in the IR spectrum, as described above for the iron(II) complex. The coordinated $\mathrm{C}=\mathrm{N}$ unit showed a stretch at 1592 $\mathrm{cm}^{-1}$, which is 47 wavenumbers lower than the free ligand. The UV-vis spectrum exhibited two strong absorptions: one was observed at $415 \mathrm{~nm}\left(\varepsilon=1257 \mathrm{~cm}^{-1} \cdot \mathrm{M}^{-1}\right)$ and the other at $506 \mathrm{~nm}\left(\varepsilon=990 \mathrm{~cm}^{-1} \cdot \mathrm{M}^{-1}\right)$. Based on the values of the molar absorption coefficients, we again ascribed the transitions to a charge-transfer process. Unfortunately, neither FAB nor EI mass spectrometry gave a molecular ion peak that corresponded to the proposed molecular structure; however, the elemental analysis was in full agreement with the formulation $\left[8 \mathrm{Fe}(\mu \mathrm{Cl})_{3} \mathrm{FeCl}_{3}\right]$. Structurally related iron clusters have been previously reported in the literature, ${ }^{41}$ and we, thus, consider that the suggested formulation $\left[\mathbf{8 F e}(\mu \mathrm{Cl})_{3} \mathrm{FeCl}_{3}\right]$ was sufficiently corroborated by IR spectroscopy, elemental analysis and literature precedents.

To unequivocally establish the structures of the new iron complexes, we undertook substantial effort to grow crystals for X-ray diffraction studies; however, only for com- plex $\left[\mathrm{FeCl}_{2} 8\right]$ were crystals obtained through slow diffusion of pentane into a dichloromethane solution of the complex at $-20^{\circ} \mathrm{C}$ over a course of one week. Crystallographic parameters are given in Table 1, and key bond lengths and angles are compiled in Table 2 . As can be seen from the molecular structure (Figure 2), the crystal contained a binuclear structure, where two iron centers are bridged by an oxo ligand. One of the two iron centers bears the ligand $\mathbf{8}$, whereas the other one is coordinated by three chloro ligands. The structure is, thus, best described as $\left[8 \mathrm{ClFe}(\mu \mathrm{O}) \mathrm{FeCl}_{3}\right]$ and the oxidation states of the two iron centers in the complex increased from iron(II) to iron(III). The formation of the oxo-bridged dimer must have taken place during the crystallization process, as the

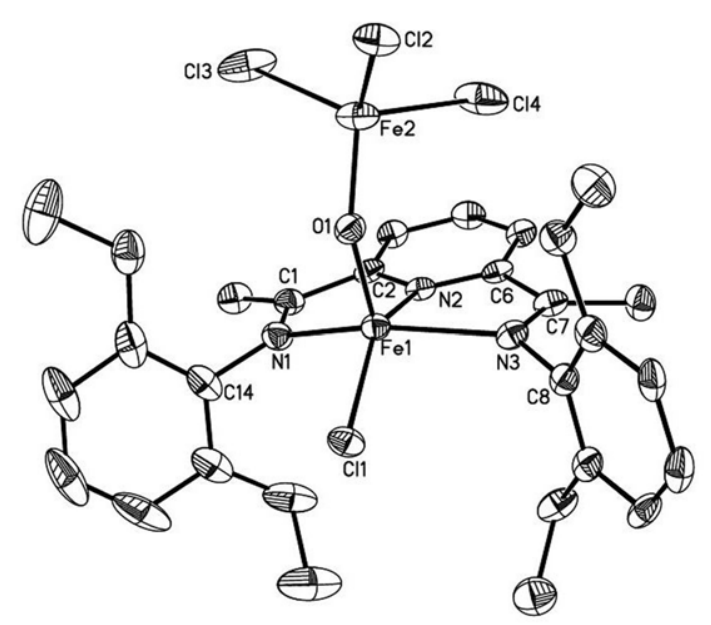

Figure 2 X-ray structure of $\left[8 \mathrm{ClFe}(\mu \mathrm{O}) \mathrm{FeCl}_{3}\right]$. Crystallographic parameters are compiled in Table 1, and key bond lengths and angles are listed in Table 2.

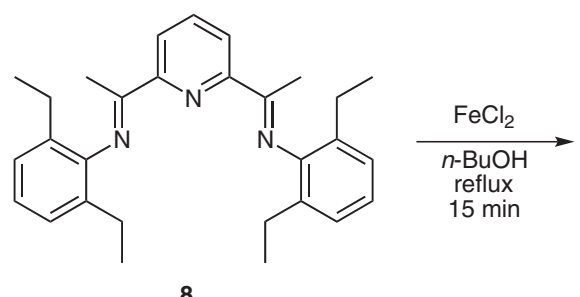<smiles>CCOCCO</smiles>

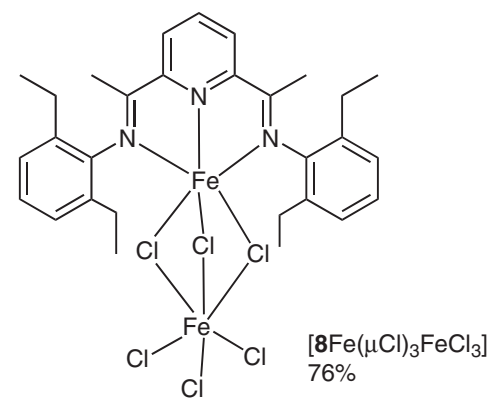<smiles></smiles>

$\left[\mathrm{FeCl}_{2} 8\right], 55 \%$

[O]

one week in solution

$\checkmark$

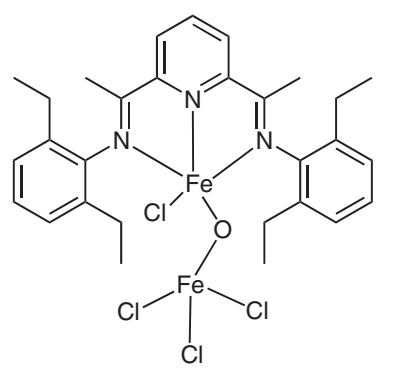

Scheme 2 Synthesis of iron(II) and iron(III) complexes of ligand $\mathbf{8}$ 
original complex $\left[\mathrm{FeCl}_{2} \mathbf{8}\right]$ exhibited an iron(II) center and its molecular formula has been established by MS and elemental analysis. Considering the long crystallization process, it appears reasonable to assume that the complex was oxidized in solution over time. Further analysis of the oxidized material by NMR spectroscopy and ESI-MS failed; due to the paramagnetism of the sample, no NMR spectra could be recorded, and the ESI-MS (for the spectrum, see the Supporting Information) did not exhibit peaks that can be assigned to the oxidized material or fragments thereof. Air oxidations of similar iron(II) complex-

Table 1 Crystallographic Parameters

\begin{tabular}{|c|c|}
\hline Empirical formula & $\mathrm{C}_{29} \mathrm{H}_{35} \mathrm{Cl}_{4} \mathrm{Fe}_{2} \mathrm{~N}_{3} \mathrm{O}$ \\
\hline Formula weight & 695.10 \\
\hline Temperature & $100(2) \mathrm{K}$ \\
\hline Wavelength & $0.71073 \AA$ \\
\hline Crystal system & monoclinic \\
\hline Space group & $P 2_{1} / c$ \\
\hline \multicolumn{2}{|l|}{ Unit cell dimensions } \\
\hline$\alpha=90^{\circ}$ & $a=12.3617(10) \AA$ \\
\hline$\beta=98.340(5)^{\circ}$ & $b=21.4167(15) \AA$ \\
\hline$\gamma=90^{\circ}$ & $c=11.8660(9) \AA$ \\
\hline Volume & $3108.3(4) \AA^{3}$ \\
\hline$Z$ & 4 \\
\hline Density (calculated) & $1.485 \mathrm{Mg} / \mathrm{m}^{3}$ \\
\hline Absorption coefficient & $1.305 \mathrm{~mm}^{-1}$ \\
\hline $\mathrm{F}(000)$ & 1432 \\
\hline Crystal size & $0.349 \times 0.193 \times 0.172 \mathrm{~mm}^{3}$ \\
\hline Theta range for data collection & 1.665 to $25.371^{\circ}$ \\
\hline Index ranges & $\begin{array}{l}-14 \leq h \leq 14,-25 \leq k \leq 25 \\
-14 \leq l \leq 14\end{array}$ \\
\hline Reflections collected & 56258 \\
\hline Independent reflections & $5588\left[R_{\mathrm{int}}=0.1017\right]$ \\
\hline Completeness to theta $=25.000^{\circ}$ & $98.9 \%$ \\
\hline Absorption correction & semiempirical from equivalents \\
\hline Max and min transmission & 0.7452 and 0.6162 \\
\hline Refinement method & full-matrix least squares on $F^{2}$ \\
\hline Data/restraints/parameters & $5588 / 45 / 375$ \\
\hline Goodness-of-fit on $F^{2}$ & 1.071 \\
\hline Final $R$ indices $[\mathrm{I}>2 \sigma(\mathrm{I})]$ & $R_{1}=0.0577, w R_{2}=0.1281$ \\
\hline $\mathrm{R}$ indices (all data) & $R_{1}=0.0954, w R_{2}=0.1495$ \\
\hline Largest difference peak and hole & 0.711 and $-0.848 \mathrm{e} \cdot \AA^{-3}$ \\
\hline
\end{tabular}

es to obtain oxo-bridged iron(III) dimers have been described previously. ${ }^{48}$

The $\mathrm{O}-\mathrm{FeCl}_{3}$ fragment of the structure is best described as slightly distorted tetrahedral. The $\mathrm{Cl}-\mathrm{Fe}(2)-\mathrm{Cl}$ and $\mathrm{Cl}-$ $\mathrm{Fe}(2)-\mathrm{O}$ bond angles range from $102.73(12)^{\circ}$ to $115.5(5)^{\circ}$, and are, thus, close to $109^{\circ}$, as expected for an ideal tetrahedron. The metal center of the $8 \mathrm{ClFe}-\mathrm{O}$ fragment of the complex can be best described as square pyramidal. The $\mathrm{N}(2)-\mathrm{Fe}(1)-\mathrm{N}(3)$ and $\mathrm{N}(2)-\mathrm{Fe}(1)-\mathrm{N}(1)$ bond angles are $73.39(16)^{\circ}$ and $72.84(16)^{\circ}$, respectively, and the $\mathrm{O}(1)-\mathrm{Fe}(1)-\mathrm{N}$ and $\mathrm{O}(1)-\mathrm{Fe}(1)-\mathrm{Cl}(1)$ bond angles range from $100.48(16)^{\circ}$ to $113.10(12)^{\circ}$. Thus, the three nitrogen atoms of the ligand $\mathbf{8}$ and the chloro ligand occupy the base of the pyramid, whereas the bridging oxo unit occupies the apex. The $\mathrm{Fe}-\mathrm{Cl}$ bond lengths for both iron centers do not significantly differ and range from 2.2022(15) to 2.261(3) $\AA$. The Fe-N bond lengths were determined to range from 2.102(4) to 2.191(4) $\AA$. Iron(III) complexes are paramagnetic; bond lengths around $2.2 \AA$ are typical for high-spin iron(II) complexes, which is longer by about $0.2 \AA$ than those observed for iron(II) lowspin complexes. ${ }^{49}$ The Fe-O-Fe angle was determined to be $146.0(2)^{\circ}$, which is at the lower end of the $145^{\circ}$ to $180^{\circ}$ typically observed for that unit. ${ }^{50 a}$

The X-ray structure is similar to that reported for the thiazole complex $\left[(\mathbf{L})_{4} \mathrm{ClFe}(\mathrm{O}) \mathrm{FeCl}_{3}\right]$, where $\mathbf{L}$ is a thiazole ligand. ${ }^{50 \mathrm{~b}}$ In this complex, the $\mathrm{Fe}-\mathrm{Cl}$ bond lengths range from $2.215(2)$ to $2.387(2) \AA$ and the $\mathrm{Fe}-\mathrm{N}$ bond lengths from 2.164(5) to 2.190(4) $\AA$. They are, thus, comparable to the corresponding values in the complex $\left[8 \mathrm{ClFe}(\mu \mathrm{O}) \mathrm{FeCl}_{3}\right]$ and in other, related oxo-bridged iron dimers. ${ }^{50 \mathrm{a}, \mathrm{c}}$

The bond lengths for the $\mathrm{C}=\mathrm{N}$ imine bond for the coordinated ligand are 1.280(6) and 1.294(6) $\AA$; the C(imine)$\mathrm{C}$ (pyridyl) bond lengths $\mathrm{C}(1)-\mathrm{C}(2)$ and $\mathrm{C}(6)-\mathrm{C}(7)$ are $1.492(7)$ and 1.478(7) $\AA$, respectively. These values are very close to those found in free, closely related bis(imino)pyridine ligands. ${ }^{51}$ Thus, extensive electron delocalization from the iron(II) center to the ligand does not appear to take place. Such a formal reduction of the ligand by the iron center has been reported for related iron $(0)$ species, and resulted in significant elongation of the $\mathrm{C}=\mathrm{N}$ bond and a concomitant reduction of the $\mathrm{C}$ (imine) $-\mathrm{C}(\mathrm{pyr}-$ idyl) bond length. ${ }^{51}$

In summary, our synthetic efforts resulted in the isolation of two new iron complexes $\left[\mathrm{FeCl}_{2} \mathbf{8}\right]$ and $\left[8 \mathrm{Fe}(\mu \mathrm{Cl})_{3} \mathrm{FeCl}_{3}\right]$ that differ in the oxidation state of iron. It is interesting to note that both complexes did not behave as straightforwardly as assumed. The iron(II) complex $\left[\mathrm{FeCl}_{2} 8\right]$ appears to oxidize (in solution) over time to an oxo-bridged dimeric structure $\left[8 \mathrm{ClFe}(\mu \mathrm{O}) \mathrm{FeCl}_{3}\right]$. The formation of the complex $\left[8 \mathrm{Fe}(\mu \mathrm{Cl})_{3} \mathrm{FeCl}_{3}\right]$ was not expected as a complex of the formula $\left[\mathrm{FeCl}_{3} \mathbf{8}\right]$ was anticipated. It has previously been observed that the employment of iron chlorides as sources for the synthesis of iron complexes can result in the formation of clusters. ${ }^{41}$ These findings might be of interest in the application of in 
Table 2 Key Bond Lengths and Angles for Complex $\left[\mathbf{8 C l F e}(\mu \mathrm{O}) \mathrm{FeCl}_{3}\right]$

\begin{tabular}{|c|c|c|c|}
\hline \multicolumn{2}{|c|}{ Key bond lengths $(\AA)$} & \multicolumn{2}{|l|}{ Key bond angles $\left({ }^{\circ}\right)$} \\
\hline $\mathrm{Fe}(1)-\mathrm{O}(1)$ & $1.756(3)$ & $\mathrm{O}(1)-\mathrm{Fe}(1)-\mathrm{N}(2)$ & $101.95(15)$ \\
\hline $\mathrm{Fe}(1)-\mathrm{N}(2)$ & $2.102(4)$ & $\mathrm{O}(1)-\mathrm{Fe}(1)-\mathrm{N}(3)$ & $104.50(16)$ \\
\hline $\mathrm{Fe}(1)-\mathrm{N}(3)$ & $2.172(4)$ & $\mathrm{N}(2)-\mathrm{Fe}(1)-\mathrm{N}(3)$ & $73.39(16)$ \\
\hline $\mathrm{Fe}(1)-\mathrm{N}(1)$ & $2.191(4)$ & $\mathrm{O}(1)-\mathrm{Fe}(1)-\mathrm{N}(1)$ & $100.48(16)$ \\
\hline $\mathrm{Fe}(1)-\mathrm{Cl}(1)$ & $2.2152(14)$ & $\mathrm{N}(2)-\mathrm{Fe}(1)-\mathrm{N}(1)$ & $72.84(16)$ \\
\hline $\mathrm{Fe}(2)-\mathrm{O}(1)$ & $1.774(3)$ & $\mathrm{N}(3)-\mathrm{Fe}(1)-\mathrm{N}(1)$ & $141.29(16)$ \\
\hline $\mathrm{Fe}(2)-\mathrm{Cl}(2)$ & $2.2022(15)$ & $\mathrm{O}(1)-\mathrm{Fe}(1)-\mathrm{Cl}(1)$ & $113.10(12)$ \\
\hline $\mathrm{Fe}(2)-\mathrm{Cl}(3)$ & $2.239(4)$ & $\mathrm{N}(2)-\mathrm{Fe}(1)-\mathrm{Cl}(1)$ & $144.95(11)$ \\
\hline $\mathrm{Fe}(2)-\mathrm{Cl}(4)$ & $2.261(3)$ & $\mathrm{N}(3)-\mathrm{Fe}(1)-\mathrm{Cl}(1)$ & $97.00(11)$ \\
\hline $\mathrm{N}(1)-\mathrm{C}(1)$ & $1.280(6)$ & $\mathrm{N}(1)-\mathrm{Fe}(1)-\mathrm{Cl}(1)$ & $99.82(12)$ \\
\hline $\mathrm{N}(3)-\mathrm{C}(7)$ & $1.294(6)$ & $\mathrm{O}(1)-\mathrm{Fe}(2)-\mathrm{Cl}(2)$ & $112.31(13)$ \\
\hline $\mathrm{C}(1)-\mathrm{C}(2)$ & $1.492(7)$ & $\mathrm{O}(1)-\mathrm{Fe}(2)-\mathrm{Cl}(3)$ & $112.1(4)$ \\
\hline$C(6)-C(7)$ & $1.478(7)$ & $\mathrm{O}(1)-\mathrm{Fe}(2)-\mathrm{Cl}(4)$ & $104.47(15)$ \\
\hline $\mathrm{N}(1)-\mathrm{C}(14)$ & $1.445(7)$ & $\mathrm{Cl}(2)-\mathrm{Fe}(2)-\mathrm{Cl}(3)$ & $109.4(3)$ \\
\hline \multirow[t]{3}{*}{$\mathrm{N}(3)-\mathrm{C}(8)$} & $1.443(6)$ & $\mathrm{Cl}(2)-\mathrm{Fe}(2)-\mathrm{Cl}(4)$ & $102.73(12)$ \\
\hline & & $\mathrm{Cl}(3)-\mathrm{Fe}(2)-\mathrm{Cl}(4)$ & $115.5(5)$ \\
\hline & & $\mathrm{Fe}(1)-\mathrm{O}(1)-\mathrm{Fe}(2)$ & $146.0(2)$ \\
\hline
\end{tabular}

situ catalyst systems where $\mathrm{FeCl}_{2}$ or $\mathrm{FeCl}_{3}$ is combined with a ligand and the resulting solution is subsequently applied in catalysis. It appears that it cannot always be assumed that a mononuclear iron complex results when iron chlorides and ligands are mixed in solution.

\section{Application of the Iron Complexes in the Mukaiyama Aldol Reaction}

We next investigated the new iron complexes $\left[\mathrm{FeCl}_{2} 8\right]$ and $\left[8 \mathrm{Fe}(\mu \mathrm{Cl})_{3} \mathrm{FeCl}_{3}\right]$ for their application as catalysts in the Mukaiyama aldol reaction. The two complexes were not found to be catalytically active alone, and we decided to activate them through chloride abstraction. Accordingly, we pretreated dichloromethane solutions of the two complexes with two equivalents of $\mathrm{AgSbF}_{6}$ which should, ideally, afford dications of the general formula $[\mathrm{Fe} 8]^{2+}$ and $\left[8 \mathrm{Fe}(\mu \mathrm{Cl})_{3} \mathrm{FeCl}\right]^{2+}$. The exact nature of the two activated species in solution could not be determined; however, the chloride abstraction was evident from precipitation of a white powder after the addition of $\mathrm{AgSbF}_{6}$, presumably $\mathrm{AgCl}$, which was removed immediately before catalytic runs. After the complexes were treated with $\mathrm{AgSbF}_{6}$, a color change was also observed, and the UV-vis spectra of the complexes changed dramatically (for the UV-vis spectra, see the Supporting Information). To further ana- lyze the catalytically active species, an ESI-MS was recorded (see the Supporting Information), but it did not exhibit peaks that could be unambiguously assigned to a structure that resulted from chloride abstraction. Treatment of the two complexes with $\mathrm{AgBF}_{4}$ gave activated species that were not as efficient in catalysis as those generated by $\mathrm{AgSbF}_{6}$. We ascribe this to the low solubility of $\mathrm{AgBF}_{4}$ in dichloromethane, which might result in incomplete chloride abstraction.

The solutions of the activated iron complexes were found to be catalytically active in the Mukaiyama aldol reaction, when added to a solution of the silyl and aldehyde substrates. The results are compiled in Tables 3 and 4 (room

Table 3 Isolated Yields ${ }^{\mathrm{a}}$
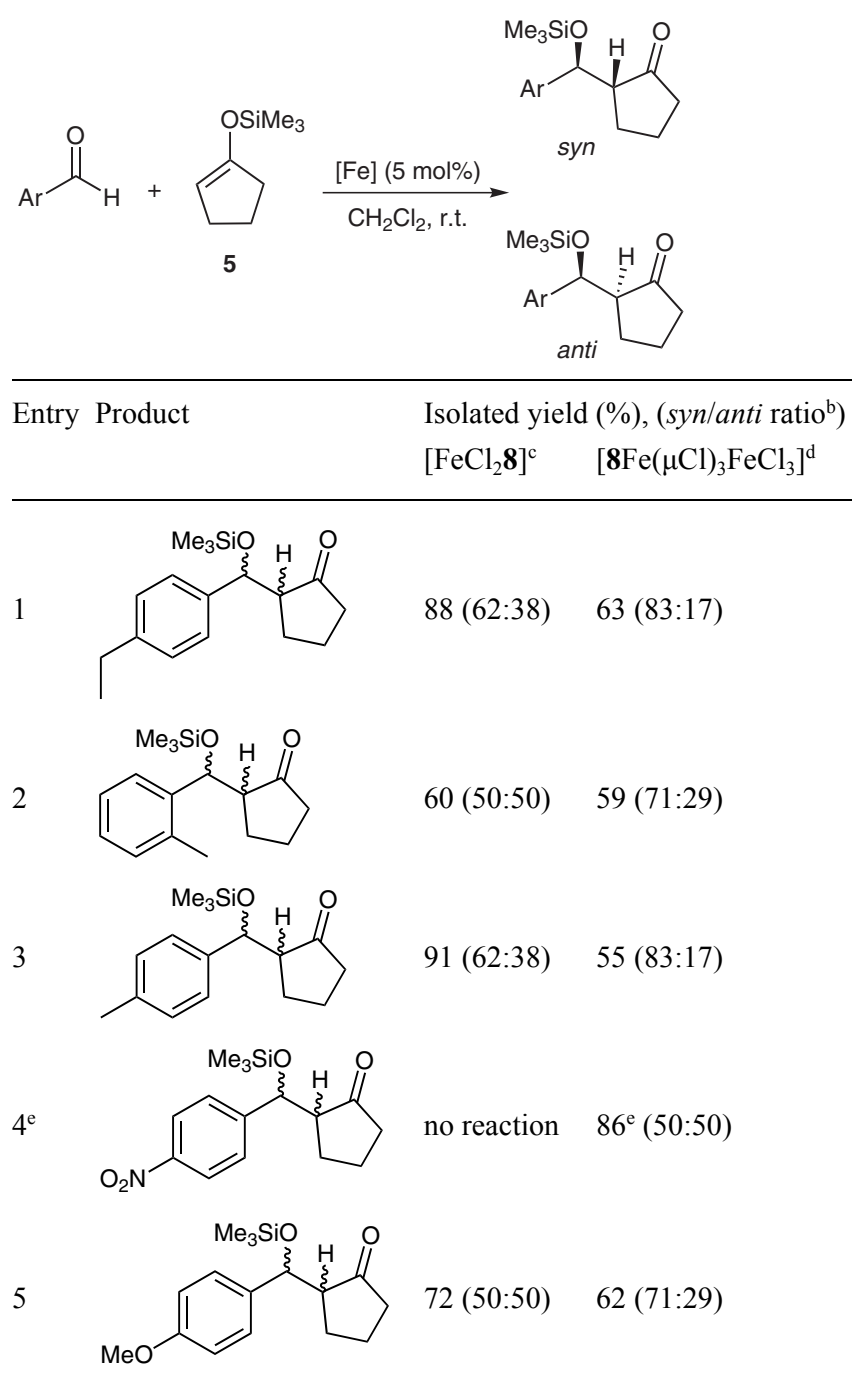

a Typical reaction conditions: aldehyde $(0.36 \mathrm{mmol})$ and silyl enol ether $(0.54 \mathrm{mmol})$ in $\mathrm{CH}_{2} \mathrm{Cl}_{2}(2 \mathrm{~mL})$ catalyzed by $[\mathrm{Fe}](0.018 \mathrm{mmol}$, activated with $0.036 \mathrm{mmol}^{\mathrm{AgSbF}_{6}}$ ) at r.t. The products were isolated by filtration through a short pad of silica gel.

${ }^{\mathrm{b}}$ Determined by ${ }^{1} \mathrm{H}$ NMR spectroscopy, based on the ${ }^{3} J_{\mathrm{HH}}$ coupling constant of the $H-\mathrm{C}-\mathrm{O}$ proton (anti: $\sim 4.5 \mathrm{~Hz}$, syn: $<1 \mathrm{~Hz}$ ).

${ }^{c} 14-16 \mathrm{~h}$ reaction time.

d $3.5 \mathrm{~h}$ reaction time.

${ }^{\mathrm{e}}$ This was the only product where the yield could not accurately be reproduced and a yield range from $10 \%$ to $90 \%$ was observed. 
Table 4 Isolated Yields ${ }^{\mathrm{a}}$

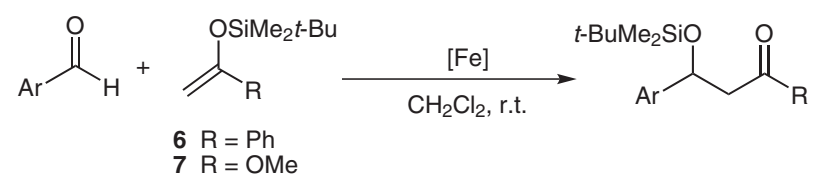

\begin{tabular}{llll}
\hline Entry $\mathrm{Ar}$ & $\mathrm{R} \quad$ Product & $\begin{array}{l}\text { Isolated } \\
\text { yield (\%) }\end{array}$ \\
\hline
\end{tabular}

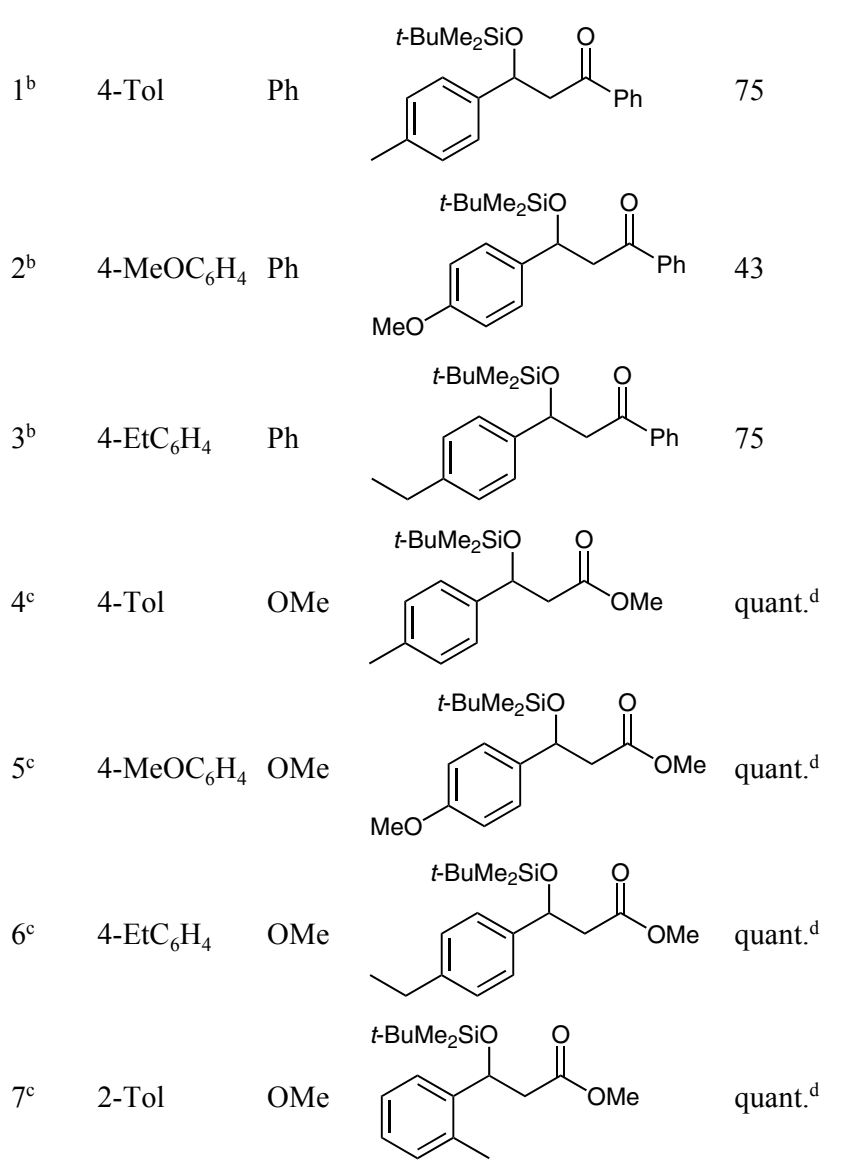

${ }^{a}$ Typical reaction conditions: aldehyde $(0.36 \mathrm{mmol})$ and silyl enol ether $(0.54 \mathrm{mmol})$ in $\mathrm{CH}_{2} \mathrm{Cl}_{2}(2 \mathrm{~mL})$ catalyzed by [Fe] $(0.018 \mathrm{mmol}$, activated with $\left.0.036 \mathrm{mmol} \mathrm{AgSbF}_{6}\right)$ at r.t. The products were isolated by filtration through a short pad of silica gel.

${ }^{\mathrm{b}}$ Utilizing the $\left[8 \mathrm{Fe}(\mu \mathrm{Cl})_{3} \mathrm{FeCl}_{3}\right]$ precursor, $3.5 \mathrm{~h}$ reaction time.

${ }^{\mathrm{c}}$ Utilizing the $\left[\mathrm{FeCl}_{2} 8\right]$ precursor, $14-16 \mathrm{~h}$ reaction time.

${ }^{\mathrm{d}}$ Virtually quantitative mass recovery; the products contained up to 5 mol\% silane side products, as assessed by NMR spectroscopy.

temperature in $\mathrm{CH}_{2} \mathrm{Cl}_{2}$, catalyst loading $5 \mathrm{~mol} \%$ ). As can be seen from the tables, the two silyl enol ethers $\mathbf{5}$ and $\mathbf{6}$, as well as the silyl ketene acetal 7, were successfully employed as nucleophiles to couple with a variety of electron-rich and electron-poor aromatic aldehydes. The products were obtained in $43 \%$ to virtually quantitative yields isolated after filtration through a short pad of silica gel to remove the catalyst. ${ }^{52}$

For the cyclic silyl enol ether substrate $\mathbf{5}$, both iron precursor complexes were tested (Table 3), and syn/anti mixtures ranging from 50:50 to 83:17 were obtained, as determined by ${ }^{1} \mathrm{H}$ NMR spectroscopy. The 2-methylbenzaldehyde substrate (Table 3, entry 2 ) gave somewhat lower yields, presumably due to steric effects exerted by the methyl group in the ortho position to the reacting aldehyde unit. A comparison of the two complexes $\left[\mathrm{FeCl}_{2} \mathbf{8}\right]$ and $\left[8 \mathrm{Fe}(\mu \mathrm{Cl})_{3} \mathrm{FeCl}_{3}\right]$ is most instructional (Table 3). It appeared that the iron(III) precursor complex $\left[\mathbf{8} \mathrm{Fe}(\mu \mathrm{Cl})_{3} \mathrm{FeCl}_{3}\right]$, after activation with $\mathrm{AgSbF}_{6}$, catalyzed the reaction more rapidly ( $3.5 \mathrm{~h}$ reaction time) than the activated iron(II) precursor complex $\left[\mathrm{FeCl}_{2} 8\right](14-16 \mathrm{~h}$ reaction time). As hypothesized, a higher oxidation state of the iron center renders the complex more reactive. However, the isolated yields were somewhat higher when the iron(II) precursor was employed as the catalyst. We tentatively ascribe the lower isolated yield to the fact that the activated iron complexes themselves also decompose the silyl enol ether substrate. The silyl nucleophiles were always employed in a slight excess, but at the end of the reaction, only aldehyde starting material and product was observed by GC.

The reaction of benzaldehyde with (trimethylsiloxy)cyclopentene 5 gave a mixture of the desired silyl-protected coupling product, the desilylated coupling product (i.e., the corresponding alcohol, exemplified in Scheme 1, compound 4) and cyclopentanone, as assessed by NMR $\left({ }^{1} \mathrm{H},{ }^{13} \mathrm{C}\left\{{ }^{1} \mathrm{H}\right\}\right.$; for the spectra, see the Supporting Information) and IR spectroscopy. Further workup efforts did not yield the desired coupling product in sufficient yield. The reaction between (trimethylsiloxy)cyclopentene $\mathbf{5}$ and both furfural and heptanal gave a multicomponent mixture, as assessed by ${ }^{1} \mathrm{H}$ NMR spectroscopy (for the spectra, see the Supporting Information), and the desired product was not observed.

When the cyclic silane $\mathbf{5}$ was added to a solution of the precursor complex $\left[\mathrm{FeCl}_{2} 8\right]$ activated with $\mathrm{AgSbF}_{6}$, the silane decomposed over the course of several hours to cyclopentanone and siloxanes such as $\mathrm{Me}_{3} \mathrm{Si}-\mathrm{O}-\mathrm{SiMe}_{3}$, as assessed by GC/MS and NMR spectroscopy $\left({ }^{1} \mathrm{H}\right.$, ${ }^{13} \mathrm{C}\left\{{ }^{1} \mathrm{H}\right\}$; for the spectra, see the Supporting Information). Similar experiments were performed with the silanes 6 and 7 , and the decomposition products were analyzed by GC/MS (for the chromatograms, see the Supporting Information). In these two cases, starting material was still present in the reaction mixture. For the silyl enol ether $\mathbf{6}$, the acetophenone decomposition product was observed in addition to $t-\mathrm{BuMe}_{2} \mathrm{Si}-\mathrm{OH}$ and other siloxanes. For the silyl ketene acetal 7, besides some unreacted 7, only $t$ $\mathrm{BuMe}_{2} \mathrm{Si}-\mathrm{OH}$ was observed on GC/MS analysis. It appears reasonable to assume that the iron(III) complex decomposes the silane substrate more rapidly than the iron(II) complex, resulting in the lower isolated yields.

The oxidation state of the iron center also had an impact on the diastereomeric ratios. As can be seen from Table 3, the syn/anti ratios for the products ranged from 50:50 to $62: 38$ when iron(II) precursor complex $\left[\mathrm{FeCl}_{2} 8\right]$ was employed as catalyst. ${ }^{53}$ These values indicate virtually no simple diastereoselection between the two achiral substrates. The syn/anti ratios ranged from 50:50 to $83: 17$ 
when the iron(III) precursor complex $\left[8 \mathrm{Fe}(\mu \mathrm{Cl})_{3} \mathrm{FeCl}_{3}\right]$ was employed. Thus, the increased oxidation state of the iron center resulted, on average, in slightly higher diastereomeric ratios. We ascribe this increase in selectivity to the fact that the iron(III) center with the higher oxidation state might create a tighter, more compact transition state, resulting in better diastereoselection. The syn/anti ratios did not change when the reactions were performed at $-76{ }^{\circ} \mathrm{C}$. Overall, the diastereoselectivities leave room for improvement and are in the range of other Mukaiyama aldol reactions that are catalyzed by metal-centered, achiral Lewis acids. ${ }^{18}$ The only report of iron(III)-catalyzed Mukaiyama aldol reactions also determined syn/anti ratios around 85:15. ${ }^{36}$

For the other two, more reactive silyl substrates 6 and 7 , we observed no significant differences between the two iron complexes, and only the results for one of the two precursor complexes are listed (Table 4). The isolated yields ranged from $43 \%$ to quantitative. We have employed the silyl ketene acetal 7 previously in Mukaiyama aldol reactions; as already noted, it is highly nucleophilic and it is, thus, not surprising that the yields are virtually quantitative (Table 4, entries 4-7) for that substrate, as the workup consists of only filtration through a short pad of silica gel.

The iron complexes described herein provide another tunable platform for iron-based catalyst systems to be employed in the Mukaiyama aldol reaction. After activation, the complexes are capable of coupling secondary (Table 3 ) and primary (Table 4) silyl enol ethers with aldehydes. The bis(imino)pyridine ligand class is tunable, and it is possible to employ chirality through the ligand. Still, the iron complexes described herein perform better than $\mathrm{FeCl}_{3}$ itself under the reaction conditions of Tables 3 and 4 in dichloromethane as a solvent. When $\mathrm{FeCl}_{3}$ was pretreated with $\mathrm{AgSbF}_{6}$ and employed in the reaction between cyclic silane $\mathbf{5}$ and 4-ethylbenzaldehyde (Table 3, entry 1), a plethora of products formed, of which the desired coupling product was a minor one, and thus is synthetically of no value. The ligand provides a beneficial effect on the catalytic performance of the iron(III) center.

The diastereoselectivities in Table 3 are not very high, but it could be possible to improve them through ligand modification (i.e., by placing bulky substituents in close proximity to the coordinating nitrogen atoms). All efforts to successfully employ a ketone substrate as carbonyl compound utilizing the catalysts described herein have failed thus far. However, through ligand modification, it might be possible to make the iron(III) catalyst even more reactive (e.g., through the introduction of more electronwithdrawing substituents on the ligand).

Herein, we have demonstrated for the first time that iron(II) and iron(III) complexes of a bis(imino)pyridine ligand are catalytically active in the Mukaiyama aldol reaction. The two iron(II) and iron(III) complexes $\left[\mathrm{FeCl}_{2} \mathbf{8}\right]$ and $\left[8 \mathrm{Fe}(\mu \mathrm{Cl})_{3} \mathrm{FeCl}_{3}\right]$ of the bis(imino)pyridine ligand $\mathbf{8}$ were synthesized and characterized, one of them also structurally. To the best of our knowledge, this is the first time that a preformed iron(III) coordination compound has been applied in the Mukaiyama aldol reaction. After activation of the catalyst through chloride abstraction, the corresponding silyl-protected $\beta$-hydroxy carbonyl compounds were obtained in $43 \%$ to quantitative yields (room temperature, 3.5 to $16 \mathrm{~h}$ reaction time, $5 \mathrm{~mol} \%$ catalyst loading). The oxidation state of the iron center has an impact on the diastereoselectivity of the reaction; the reaction time was shorter $(3.5 \mathrm{~h})$ and the syn/anti ratios for the products were somewhat higher when the iron(III) precursor complex was employed. Ligand modification studies to improve the diastereoselectivities and to potentially employ chirality are currently underway.

Solvents were treated as follows: $\mathrm{Et}_{2} \mathrm{O}$, distilled from Na/benzophenone; $\mathrm{CH}_{2} \mathrm{Cl}_{2}$, distilled from $\mathrm{CaH}_{2} ; n-\mathrm{BuOH}$, distilled from $\mathrm{Mg}$. Silica gel, $\mathrm{CHCl}_{3}, \mathrm{AgSbF}_{6}$ and $\mathrm{FeCl}_{3}$ (all Aldrich), $\mathrm{FeCl}_{2}$ (Strem) and other materials were used as received. The ligand $\mathbf{8}^{43}$ and the silyl enol ethers (cyclopent-1-en-1-yloxy)trimethylsilane $(\mathbf{5})^{54}$ and tertbutyl(dimethyl)[(1-phenylvinyl)oxy]silane $(\mathbf{6})^{55}$ were prepared according to the literature. All reactions were carried out under nitrogen employing standard Schlenk techniques, and the workup was carried out in the air. NMR spectra were obtained at r.t. on a Bruker Avance $300 \mathrm{MHz}$ or a Varian Unity Plus $300 \mathrm{MHz}$ instrument and referenced to a residual solvent signal; all assignments are tentative. GC/MS spectra were recorded on a Hewlett Packard GC/MS System Model 5988A. UV-vis spectra were recorded on a Varian Cary 50 Bio spectrophotometer. Exact masses were obtained on a JEOL MStation [JMS-700] mass spectrometer. IR spectra were recorded on a Thermo Nicolet 360 FT-IR spectrometer. Elemental analyses were performed by Atlantic Microlab Inc., Norcross, GA, USA.

\section{Complex $\left[\mathrm{FeCl}_{2} 8\right]$}

A solution of $\mathrm{FeCl}_{2}(0.025 \mathrm{~g}, 0.200 \mathrm{mmol})$ in $n-\mathrm{BuOH}(3 \mathrm{~mL})$ was added to a suspension of ligand $\mathbf{8}(0.085 \mathrm{~g}, 0.200 \mathrm{mmol})$ in $n-\mathrm{BuOH}$ $(3 \mathrm{~mL})$ at once, and the mixture was heated at $80^{\circ} \mathrm{C}$. The solution changed color from yellow to blue instantaneously. The reaction mixture was stirred at $80^{\circ} \mathrm{C}$ for another $15 \mathrm{~min}$, then was concentrated to about $1 \mathrm{~mL}$ under high vacuum. A blue solid precipitated. Anhyd pentane $(5 \mathrm{~mL})$ was added; the suspension was allowed to stir for $10 \mathrm{~min}$ and the mother liquor was decanted. The solid was washed several times with anhyd pentane ( $3 \mathrm{~mL}$ at a time), until the supernatant was almost colorless. The blue solid was dried under high vacuum for $2 \mathrm{~d}$. The complex was obtained as a blue solid $(0.061 \mathrm{~g}, 0.111 \mathrm{mmol})$ in $55 \%$ isolated yield.

IR (neat solid): $1621(\mathrm{~m}), 1585(\mathrm{~s}, \mathrm{C}=\mathrm{N}), 1446(\mathrm{~s}), 1372(\mathrm{~s}) \mathrm{cm}^{-1}$.

MS (FAB, 4-NBA): $m / z(\%)=551(25)[\mathrm{M}]^{+}, 516(100)[\mathrm{M}-\mathrm{Cl}]^{+}$, $426(10)[8+\mathrm{H}]^{+}$.

HRMS-FAB: $m / z$ [ $\left.\mathrm{FeCl}_{2} \mathbf{8}\right]^{+}$calcd for $\mathrm{C}_{29} \mathrm{H}_{35}{ }^{35} \mathrm{Cl}_{2} \mathrm{~N}_{3} \mathrm{Fe}$ : 551.1557; found: $551.1543 ; \mathrm{m} / z$ [FeCl8 $]^{+}$calcd for $\mathrm{C}_{29} \mathrm{H}_{35}{ }^{35} \mathrm{ClN}_{3} \mathrm{Fe}$ : 516.1869; found: 516.1865 .

UV/Vis $\left(\mathrm{CH}_{2} \mathrm{Cl}_{2}\right): \lambda_{\max }(\varepsilon)=698(1164) \mathrm{nm}$.

Anal. Calcd for $\mathrm{C}_{29} \mathrm{H}_{35} \mathrm{Cl}_{2} \mathrm{~N}_{3} \mathrm{Fe}$ : C, 63.06; $\mathrm{H}, 6.34$. Found: $\mathrm{C}, 62.29$; H, 6.34 .

\section{Complex $\left[8 \mathrm{Fe}(\mu \mathrm{Cl})_{3} \mathrm{FeCl}_{3}\right]$}

A solution of $\mathrm{FeCl}_{3}(0.038 \mathrm{~g}, 0.234 \mathrm{mmol})$ in $\mathrm{Et}_{2} \mathrm{O}(4 \mathrm{~mL})$ was added to a solution of ligand $8(0.100 \mathrm{~g}, 0.234 \mathrm{mmol})$ in anhyd $\mathrm{Et}_{2} \mathrm{O}(6$ $\mathrm{mL}$ ) dropwise over $5 \mathrm{~min}$. An orange-red solid precipitated almost immediately. The reaction mixture was stirred at r.t. for another 15 min, then the supernatant was decanted. The orange-red solid was washed with $\mathrm{Et}_{2} \mathrm{O}(5 \mathrm{~mL})$ several times, until the supernatant did not show a yellow coloration, and then dried under high vacuum for 2 
$\mathrm{d}$. The product was obtained as an orange-red solid $(0.067 \mathrm{~g}, 0.09$ $\mathrm{mmol}$ ) in $76 \%$ isolated yield.

IR (neat solid): $1626(\mathrm{~m}), 1592(\mathrm{~s}, \mathrm{C}=\mathrm{N}), 1370(\mathrm{~s}), 1265(\mathrm{~s}) \mathrm{cm}^{-1}$.

MS (FAB, 4-NBA): $m / z(\%)=551$ (35) $\left[\mathrm{FeCl}_{2} 8\right]^{+}, 516(100)$ $[\mathrm{FeCl8}]^{+}, 426(15)[8+\mathrm{H}]^{+}$.

HRMS-FAB: $m / z$ [ $\left.\mathrm{FeCl}_{2} 8\right]^{+}$calcd for $\mathrm{C}_{29} \mathrm{H}_{35}{ }^{35} \mathrm{Cl}_{2} \mathrm{~N}_{3} \mathrm{Fe}$ : 551.1557; found: 551.1578 .

UV/Vis $\left(\mathrm{CH}_{2} \mathrm{Cl}_{2}\right): \lambda_{\max }(\varepsilon)=415(1257), 506(990) \mathrm{nm}$.

Anal. Calcd for $\mathrm{C}_{29} \mathrm{H}_{35} \mathrm{Cl}_{6} \mathrm{~N}_{3} \mathrm{Fe}_{2}$ : C, 46.44; $\mathrm{H}, 4.70$. Found: $\mathrm{C}$, 46.24; H, 4.81.

Catalysis Experiment (Table 3, Entry 1); Typical Procedure The complex $\left[\mathrm{FeCl}_{2} 8\right](0.010 \mathrm{~g}, 0.018 \mathrm{mmol})$ was dissolved in $\mathrm{CH}_{2} \mathrm{Cl}_{2}(0.5 \mathrm{~mL})$, and in another flask $\mathrm{AgSbF}_{6}(0.012 \mathrm{~g}, 0.036$ $\mathrm{mmol})$ was dissolved in $\mathrm{CH}_{2} \mathrm{Cl}_{2}(0.5 \mathrm{~mL})$. The solution of $\mathrm{AgSbF}_{6}$ was added to the solution of the metal complex and stirred at r.t. for $1 \mathrm{~h}$. In a third flask, 4-ethylbenzaldehyde $(0.049 \mathrm{~g}, 0.362 \mathrm{mmol})$ and the silane $5(0.085 \mathrm{~g}, 0.543 \mathrm{mmol})$ were mixed in $\mathrm{CH}_{2} \mathrm{Cl}_{2}(1 \mathrm{~mL})$ and stirred at r.t. for $3.5 \mathrm{~h}$. The solution of the activated catalyst was then filtered through Celite ${ }^{\circledR}$ directly into the solution of the substrates, and the color of the solution turned to reddish. The reaction mixture was stirred overnight, then filtered through a pad of silica gel $(3.5 \mathrm{~cm})$. The silica gel was washed with $\mathrm{CH}_{2} \mathrm{Cl}_{2}$ (about $2 \mathrm{~mL}$ ) and the filtrate was concentrated. The yellow residue that was obtained was $95 \%$ pure ( ${ }^{1} \mathrm{H}$ NMR spectroscopy), and any further purification gave only decomposition products, and elution with extremely nonpolar solvents like hexanes also yielded small amounts of silyl impurities (about 5\%). The product was obtained in $95 \%$ purity as a yellow oil $(0.093 \mathrm{~g}, 0.319 \mathrm{mmol})$ in $88 \%$ yield, as a mixture of diastereomers $(62: 38)$ as determined by ${ }^{1} \mathrm{H}$ NMR spectroscopy.

${ }^{1} \mathrm{H}$ NMR $\left(300 \mathrm{MHz}, \mathrm{CDCl}_{3}\right): \delta=7.23-7.09(\mathrm{~m}, 6 \mathrm{H}, 4 \mathrm{H}+2 \mathrm{H}$, Ar), $5.30\left[\mathrm{~d},{ }^{3} J_{\mathrm{HH}}=1.0 \mathrm{~Hz}, 1 \mathrm{H}, \mathrm{CHOSi}\left(\mathrm{CH}_{3}\right)_{3}\right], 5.17\left[\mathrm{~d},{ }^{3} J_{\mathrm{HH}}=4.5\right.$ $\left.\mathrm{Hz}, 0.6 \mathrm{H}, \mathrm{CH}^{\prime} \mathrm{OSi}\left(\mathrm{CH}_{3}\right)_{3}\right], 2.68-2.59\left(\mathrm{~m}, 4 \mathrm{H}, \mathrm{CH}_{2} \mathrm{CH}_{3}+\mathrm{CHCO}\right.$, $\left.\mathrm{CH}_{2}{ }^{\prime} \mathrm{CH}_{3}+\mathrm{CH}{ }^{\prime} \mathrm{CO}\right), 2.29-1.99\left(\mathrm{~m}, 11 \mathrm{H}, \mathrm{CH}_{2}+\mathrm{CH}_{2}{ }^{\prime}\right), 1.27-1.20$ $\left(\mathrm{m}, 5 \mathrm{H}, \mathrm{CH}_{3}+\mathrm{CH}_{3}{ }^{\prime}\right), 0.06\left(\mathrm{~s}, 5 \mathrm{H}, \mathrm{OSiCH}_{3}{ }^{\prime}\right), 0.01(\mathrm{~s}, 9 \mathrm{H}$, $\mathrm{OSiCH}_{3}$ ).

${ }^{13} \mathrm{C}\left\{{ }^{1} \mathrm{H}\right\} \operatorname{NMR}\left(75.4 \mathrm{MHz}, \mathrm{CDCl}_{3}\right): \delta=223.4\left(C^{\prime}=\mathrm{O}\right), 220.1(C=\mathrm{O})$, 144.2, 142.8, 141.2, 138.9, 130.5, 128.1, 127.7, 127.5, 126.7, 126.6 125.6, $75.2\left[\mathrm{CHOSi}\left(\mathrm{CH}_{3}\right)_{3}\right], 72.5\left[\mathrm{C}^{\prime} \mathrm{HOSi}\left(\mathrm{CH}_{3}\right)_{3}\right], 57.5(\mathrm{CHCO})$, 55.5 ( $\left.C^{\prime} \mathrm{HCO}\right), 39.8,38.9,28.7,27.2,24.8,21.0,20.6,15.7,15.6$, $0.2\left(\mathrm{SiCH}_{3}\right), 0.1\left(\mathrm{SiC}^{\prime} \mathrm{H}_{3}\right)$.

MS (EI): $m / z(\%)=216(35)\left[\mathrm{M}-\mathrm{Si}\left(\mathrm{CH}_{3}\right)_{3}+\mathrm{H}\right]^{+}, 200(60)[\mathrm{M}-$ $\left.\mathrm{OSi}\left(\mathrm{CH}_{3}\right)_{3}+\mathrm{H}\right]^{+}, 135(100)\left[\mathrm{M}-\mathrm{Si}\left(\mathrm{CH}_{3}\right)_{3}-\mathrm{C}_{5} \mathrm{H}_{7} \mathrm{O}+\mathrm{H}\right]^{+}$.

\section{$\mathrm{X}$-ray Structure Determination of $\left[\mathrm{BCIFe}(\mu \mathrm{O}) \mathrm{FeCl}_{3}\right]$}

Crystals of appropriate dimension were obtained by slow vapor diffusion of pentane into a $\mathrm{CH}_{2} \mathrm{Cl}_{2}$ solution of complex $\left[\mathrm{FeCl}_{2} 8\right]$. A crystal with approximate dimensions $0.17 \times 0.19 \times 0.35 \mathrm{~mm}^{3}$ was mounted on a MiTeGen cryoloop in a random orientation. Preliminary examination and data collection were performed using a Bruker Kappa Apex II CCD (charge-coupled device) detector system single-crystal X-ray diffractometer equipped with an Oxford Cryostream LT device. All data were collected using graphite monochromated Mo K $\alpha$ radiation $(\lambda=0.71073 \AA)$ from a fine-focus sealed tube X-ray source. Preliminary unit cell constants were determined with a set of 36 narrow frame scans. Typical data sets consist of combinations of $\omega$ and $\Phi$ scan frames with typical scan width of $0.5^{\circ}$ and counting time of 15 seconds/frame at a crystal-to-detector distance of $4.0 \mathrm{~cm}$. The collected frames were integrated using an orientation matrix determined from the narrow frame scans. Apex II and SAINT software packages ${ }^{56}$ were used for data collection and data integration. Analysis of the integrated data did not show any decay. Final cell constants were determined by global refinement of $x y z$ centroids of 9423 reflections from the complete data set. Collected data were corrected for systematic errors using SADABS ${ }^{56}$ based on the Laue symmetry using equivalent reflections. Crystal data and intensity data collection parameters are listed in Table 1. Structure solution and refinement were carried out using the SHELXTL-PLUS software package..$^{57}$ The structure was solved by direct methods and refined successfully in the space group $P 2_{1} / c$. Full-matrix least-squares refinement was carried out by minimizing $\Sigma w\left(F_{\mathrm{o}}{ }^{2}-F_{\mathrm{c}}{ }^{2}\right)^{2}$. The non-hydrogen atoms were refined anisotropically to convergence. All hydrogen atoms were treated using the appropriate riding model (AFIX $\mathrm{m} 3$ ). The disorder in the $\mathrm{FeCl}_{3}$ unit was resolved with partial occupancy $\mathrm{Cl}$ atoms and the disordered atoms were refined with geometrical and displacement parameter restraints and constraints. The structure refinement converged to the residual values of $R_{1}=5.8 \%$ and $w R_{2}=14.9 \%$. The final structure refinement parameters are listed in Table 1 .

CCDC 950588 contains the supplementary crystallographic data for this paper. These data can be obtained free of charge from The Cambridge Crystallographic Data Centre via www.ccdc.cam.ac.uk/data_request/cif.

\section{Acknowledgment}

We would like to thank the University of Missouri-St. Louis College of Arts and Sciences Research Award for financial support. Funding from the National Science Foundation for the purchase of the NMR spectrometer (CHE-9974801), the purchase of the Apex II diffractometer (MRI, CHE-0420497) and the purchase of the mass spectrometer (CHE-9708640) is acknowledged.

Supporting Information for this article is available online at http://www.thieme-connect.com/ejournals/toc/synthesis.

\section{References}

(1) (a) Pansare, S. V.; Paul, E. K. Chem. Eur. J. 2011, 17, 8770. (b) García, J. M.; Oiarbide, M.; Palomo, C. Angew. Chem. Int. Ed. 2011, 50, 8790. (c) Palomo, C.; Oiarbide, M.; García, J. M. Chem. Eur. J. 2002, 8, 37.

(2) (a) Mukaiyama, T.; Narasaka, K.; Banno, K. Chem. Lett. 1973, 1011. (b) Mukaiyama, T.; Banno, K.; Narasaka, K. J. Am. Chem. Soc. 1974, 96, 7503.

(3) (a) Bielitza, M.; Pietruszka, J. Chem. Eur. J. 2013, 19, 8300. (b) Abe, H.; Sato, A.; Kobayashi, T.; Ito, H. Org. Lett. 2013, 15, 1298. (c) Yadav, J. S.; Reddy, A. B.; Shankar, K. S. Synthesis 2013, 45, 1034. (d) Sharpe, R. J.; Jennings, M. P. J. Org. Chem. 2011, 76, 8027. (e) Brodmann, T.; Lorenz, M.; Schäckel, R.; Simsek, S.; Kalesse, M. Synlett 2009, 174.

(4) (a) Cheon, C. H.; Yamamoto, H. Org. Lett. 2010, 12, 2476. (b) Cheon, C. H.; Yamamoto, H. Tetrahedron 2010, 66, 4257. (c) Ratnikov, M. O.; Tumanov, V. V.; Smit, W. A. Angew. Chem. Int. Ed. 2008, 47, 9739.

(5) Qiu, R.; Chen, Y.; Yin, S.-F.; Xu, X.; Au, C.-T. RSC Adv. 2012, 2, 10774.

(6) Röttger, D.; Erker, G.; Grehl, M.; Fröhlich, R. Organometallics 1994, 13, 3897.

(7) (a) Ollevier, T.; Desyroy, V.; Debailleul, B.; Vaur, S. Eur. J. Org. Chem. 2005, 4971. (b) Le Roux, C.; GaspardIloughmane, H.; Dubac, J.; Jaud, J.; Vignaux, P. J. Org. Chem. 1993, 58, 1835.

(8) Ishihara, K.; Kondo, S.; Yamamoto, H. J. Org. Chem. 2000, 65,9125

(9) Mikami, K.; Matsukawa, S.; Kayaki, Y.; Ikariya, T. Tetrahedron Lett. 2000, 41, 1931.

(10) Kiyooka, S.; Matsumoto, S.; Kojima, M.; Sakonaka, K.; Maeda, H. Tetrahedron Lett. 2008, 49, 1589.

(11) Nishiyama, Y.; Kaiba, K.; Umeda, R. Tetrahedron Lett. 2010, 51, 793 . 
(12) (a) Sudha, R.; Sankararaman, S. J. Chem. Soc., Perkin Trans. 1 1999, 383. (b) Reetz, M. T.; Fox, D. N. A. Tetrahedron Lett. 1993, 34, 1119.

(13) Han, J. S.; Kim, S. B.; Mukaiyama, T. Bull. Korean Chem. Soc. 1994, 15, 529.

(14) Olmos, A.; Alix, A.; Sommer, J.; Pale, P. Chem. Eur. J. 2009, 15, 11229.

(15) (a) Mlynarski, J.; Jankowska, J. Adv. Synth. Catal. 2005, 347, 521. (b) Evans, D. A.; Kozlowski, M. C.; Tedrow, J. S. Tetrahedron Lett. 1996, 37, 7481.

(16) (a) Denmark, S. E.; Beutner, G. L.; Wynn, T.; Eastgate, M. D. J. Am. Chem. Soc. 2005, 127, 3774. (b) Denmark, S. E.; Beutner, G. L.; Wynn, T. J. Am. Chem. Soc. 2002, 124, 13405.

(17) Mukaiyama, T.; Matsui, S.; Kashiwagi, K. Chem. Lett. 1989 , 993.

(18) (a) García-García, P.; Lay, F.; García-García, P.; Rabalakos, C.; List, B. Angew. Chem. Int. Ed. 2009, 48, 4363.

(b) Heathcock, C. H.; Davidsen, S. K.; Hug, K. T.; Flippin, L. A. J. Org. Chem. 1986, 51, 3027.

(19) Lee, J. M.; Helquist, P.; Wiest, O. J. Am. Chem. Soc. 2012, $134,14973$.

(20) Mahrwald, R. Chem. Rev. 1999, 99, 1095.

(21) Mayr, H.; Kempf, B.; Ofial, A. R. Acc. Chem. Res. 2003, 36, 66.

(22) (a) Mei, Y.; Averill, D. J.; Allen, M. J. J. Org. Chem. 2012, 77, 5624. (b) Mei, Y.; Dissanayake, P.; Allen, M. J. J. Am. Chem. Soc. 2010, 132, 12871. (c) Gu, Y.; Ogawa, C.; Kobayashi, J.; Mori, Y.; Kobayashi, S. Angew. Chem. Int. Ed. 2006, 45, 7217. (d) Kobayashi, S.; Nagayama, S.; Busujima, T. J. Am. Chem. Soc. 1998, 120, 8287.

(23) (a) Lenze, M.; Sedinkin, S. L.; Rath, N. P.; Bauer, E. B. Tetrahedron Lett. 2010, 51, 2855. (b) Tanabe, K. K.; Cohen, S. M. Angew. Chem. Int. Ed. 2009, 48, 7424. (c) Jankowska, J.; Paradowska, J.; Rakiel, B.; Mlynarski, J. J. Org. Chem. 2007, 72, 2228. (d) Jankowska, J.; Paradowska, J.; Mlynarski, J. Tetrahedron Lett. 2006, 47, 5281. (e) Bach, T.; Fox, D. N. A.; Reetz, M. T. J. Chem. Soc., Chem. Commun. $1992,1634$.

(24) (a) Plancq, B.; Ollevier, T. Aust. J. Chem. 2012, 65, 1564.

(b) Ollevier, T.; Plancq, B. Chem. Commun. 2012, 48, 2289.

(25) (a) Gopalaiah, K. Chem. Rev. 2013, 113, 3248. (b) Sun, X.; Li, J.; Huang, X.; Sun, C. Curr. Inorg. Chem. 2012, 2, 64. (c) Sun, C.-L.; Li, B.-J.; Shi, Z.-J. Chem. Rev. 2011, 111, 1293. (d) Czaplik, W. M.; Mayer, M.; Cvengroš, J.; Jacobi von Wangelin, A. ChemSusChem 2009, 2, 396. (e) Sarhan, A. A. O.; Bolm, C. Chem. Soc. Rev. 2009, 38, 2730. (f) Bauer, E. B. Curr. Org. Chem. 2008, 12, 1341. (g) Enthaler, S.; Junge, K.; Beller, M. Angew. Chem. Int. Ed. 2008, 47, 3317. (h) Correra, A.; Garcia Mancheño, O.; Bolm, C. Chem. Soc. Rev. 2008, 37, 1108. (i) Sherry, B. D.; Fürstner, A. Acc. Chem. Res. 2008, 41, 1500. (j) Bolm, C.; Legros, J.; Le Paih, J.; Zani, L. Chem. Rev. 2004, 104, 6217.

(26) (a) Chen, Y.; Li, K.; Liu, X.; Zhu, J.; Chen, B. Synlett 2013, 24, 130. (b) Hata, T.; Iwata, S.; Seto, S.; Urabe, H. Adv. Synth. Catal. 2012, 354, 1885. (c) Gülak, S.; Jacobi von Wangelin, A. Angew. Chem. Int. Ed. 2012, 51, 1357. (d) Lin, M.; Chen, X.-1.; Wang, T.; Yan, P.; Xu, S.-x.; Zhan, Z.-p. Chem. Lett. 2011, 40, 111. (e) Midya, G. C.; Paladhi, S.; Dhara, K.; Dash, J. Chem. Commun. 2011, 47, 6698. (f) Mayer, M.; Czaplik, W. M.; Jacobi von Wangelin, A. Adv. Synth. Catal. 2010, 352, 2147.

(27) Bonnamour, J.; Bolm, C. Org. Lett. 2011, 13, 2012.

(28) Han, W.; Mayer, P.; Ofial, A. R. Adv. Synth. Catal. 2010 , $352,1667$.

(29) Haberberger, M.; Enthaler, S. Chem. Asian J. 2013, 8, 50.
(30) Blom, B.; Enthaler, S.; Inoue, S.; Irran, E.; Driess, M. J. Am. Chem. Soc. 2013, 135, 6703.

(31) García Mancheño, O.; Dallimore, J.; Plant, A.; Bolm, C. Org. Lett. 2009, 11, 2429.

(32) (a) Berkessel, A.; Reichau, S.; von der Höh, A.; Leconte, N.; Neudörfl, J.-M. Organometallics 2011, 30, 3880. (b) Yang, J.; Tilley, T. D. Angew. Chem. Int. Ed. 2010, 49, 10186.

(c) Flückiger, M.; Togni, A. Eur. J. Org. Chem. 2011, 4353. (d) Cardoso, J. M. S.; Royo, B. Chem. Commun. 2012, 48, 4944.

(33) (a) Fernandes, R. R.; Lasri, J.; Guedes da Silva, M. F. C.; da Silva, J. A. L.; Frausto da Silva, J. J. R.; Pombeiro, A. J. L. J. Mol. Catal. A: Chem. 2011, 351, 100. (b) Moyer, S. A.; Funk, T. W. Tetrahedron Lett. 2010, 51, 5430. (c) BaloghHergovich, E.; Speier, G. J. Mol. Catal. A: Chem. 2005, 230, 79. (d) Hosseini-Monfared, H.; Näther, C.; Winkler, H.; Janiak, C. Inorg. Chim. Acta 2012, 391, 75. (e) Comba, P.; Wadepohl, H.; Wunderlich, S. Eur. J. Inorg. Chem. 2011, 5242. (f) Shaikha, T. M.; Hong, F. E. Adv. Synth. Catal. 2011, 353, 1491. (g) Wu, M.; Miao, C.-X.; Wang, S.; Hu, X.; Xia, C.; Kühn, F. E.; Sun, W. Adv. Synth. Catal. 2011, 353, 3014. (h) Schröder, K.; Join, B.; Amali, A. J.; Junge, K.; Ribas, X.; Costas, M.; Beller, M. Angew. Chem. Int. Ed. 2011, 50, 1425. (i) Gelalcha, F. G.; Anilkumar, G.; Tse, M. K.; Brückner, A.; Beller, M. Chem. Eur. J. 2008, 14, 7687. (j) Bruijnincx, P. C. A.; Buurmans, I. L. C.; Gosiewska, S.; Moelands, M. A. H.; Lutz, M.; Spek, A. L.; van Koten, G.; Klein Gebbink, R. J. M. Chem. Eur. J. 2008, 14, 1228. (k) Oddon, F.; Girgenti, E.; Lebrun, C.; Marchi-Delapierre, C.; Pécaut, J.; Ménage, S. Eur. J. Inorg. Chem. 2012, 85. (1) Liu, S.-G.; Zhou, X.-T.; Ji, H.-B. Catal. Commun. 2013, 37, 60. (m) Clemente-Tejeda, D.; Lopez-Moreno, A.; Bermejo, F. A. Tetrahedron 2013, 69, 2977. (n) Lenze, M.; Bauer, E. B. Chem. Commun. 2013, 49, 5889. (o) Lenze, M.; Martin, E. T.; Rath, N. P.; Bauer, E. B. ChemPlusChem 2013, 78, 101. (p) Christmann, M. Angew. Chem. Int. Ed. 2008, 47, 2740.

(34) Tondreau, A. M.; Milsmann, C.; Patrick, A. D.; Hoyt, H. M.; Lobkovsky, E.; Wieghardt, K.; Chirik, P. J. J. Am. Chem. Soc. 2010, 132, 15046.

(35) (a) Lin, Y.-Y.; Wang, Y.-J.; Lin, C.-H.; Cheng, J.-H.; Lee, C.-F. J. Org. Chem. 2012, 77, 6100. (b) Bézier, D.;

Venkanna, G. T.; Misal Castro, L. C.; Zheng, J.; Roisnel, T.; Sortais, J.-B.; Darcel, C. Adv. Synth. Catal. 2012, 354, 1879. (c) Enthaler, S. Eur. J. Org. Chem. 2011, 4760. (d) Wang, C.; Li, X.; Wu, F.; Wan, B. Angew. Chem. Int. Ed. 2011, 50, 7162.

(36) Aoyama, N.; Manabe, K.; Kobayashi, S. Chem. Lett. 2004, 33,312 .

(37) Cámpora, J.; Ángeles Cartes, M.; Rodríguez-Delgado, A.; Marcos Naz, A.; Palma, P.; Pérez, C. M. Inorg. Chem. 2009, 48,3679

(38) (a) Tondreau, A. M.; Stieber, C. E.; Milsmann, C.; Lobkovsky, E.; Weyhermüller, T.; Semproni, S. P.; Chirik, P. J. Inorg. Chem. 2013, 52, 635. (b) Tondreau, A. M.; Milsmann, C.; Lobkovsky, E.; Chirik, P. J. Inorg. Chem. 2011, 50, 9888 .

(39) (a) Wang, S.; Li, B.; Liang, T.; Redshaw, C.; Lib, Y.; Sun, W.-H. Dalton Trans. 2013, 42, 9188. (b) Smit, T. M.; Tomov, A. K.; Britovsek, G. J. P.; Gibson, V. C.; White, A. J. P.; Williams, D. J. Catal. Sci. Technol. 2012, 2, 643. (c) Görl, C.; Englmann, T.; Alt, H. G. Appl. Catal., A 2011, 403, 25. (d) Appukuttan, V. K.; Liu, Y.; Son, B. C.; Ha, C.S.; Suh, H.; Kim, I. Organometallics 2011, 30, 2285. (e) Tondreau, A. M.; Milsmann, C.; Patrick, A. D.; Hoyt, H. M.; Lobkovsky, E.; Wieghardt, K.; Chirik, P. J. J. Am. Chem. Soc. 2010, 132, 15046. (f) Long, Z.; Wua, B.; Yang, 
P.; Li, G.; Liu, Y.; Yang, X.-Y. J. Organomet. Chem. 2009, 694, 3793. (g) Bryliakov, K. P.; Talsi, E. P.; Semikolenova, N. V.; Zakharov, V. A. Organometallics 2009, 28, 3225. (h) Britovsek, G. J. P.; Gibson, V. C.; Spitzmesser, S. K.; Tellmann, K. P.; White, A. J. P.; Williams, D. J. J. Chem. Soc., Dalton Trans. 2002, 1159.

(40) (a) Hoyt, J. M.; Sylvester, K. T.; Semproni, S. P.; Chirik, P. J. J. Am. Chem. Soc. 2013, 135, 4862. (b) D'Souza, B. R.; Lane, T. K.; Louie, J. Org. Lett. 2011, 13, 2936.

(c) Sylvester, K. T.; Chirik, P. J. J. Am. Chem. Soc. 2009, 131,8772 .

(41) (a) Eames, E. V.; Sánchez, R. H.; Betley, T. A. Inorg. Chem. 2013, 52, 5006. (b) Yang, M.; Kim, E.; Jeong, J. H.; Min, K. S.; Lee, H. Inorg. Chim. Acta 2013, 394, 501. (c) Duncan, J. S.; Zdilla, M. J.; Lee, S. C. Inorg. Chem. 2007, 46, 1071. (d) Nienkemper, K.; Kotov, V. V.; Kehr, G.; Erker, G.; Fröhlich, R. Eur. J. Inorg. Chem. 2006, 366. (e) Kreischer, K.; Kipke, J.; Bauerfeind, M.; Sundermeyer, J. Z. Anorg. Allg. Chem. 2001, 627, 1023 .

(42) Schmidt, R.; Welch, M. B.; Knudsen, R. D.; Gottfried, S.; Alt, H. G. J. Mol. Catal. A: Chem. 2004, 222, 9.

(43) Esteruelas, M. A.; López, A. M.; Méndez, L.; Oliván, M.; Oñate, E. Organometallics 2003, 22, 395.

(44) Lenze, M.; Bauer, E. B. J. Mol. Catal. A: Chem. 2009, 309, 117.

(45) Görl, C.; Alt, H. G. J. Mol. Catal. A: Chem. 2007, 273, 118.

(46) (a) Shejwalkar, P.; Rath, N. P.; Bauer, E. B. Dalton Trans. 2011, 40, 7617. (b) Souza, V. R.; Rechenberg, H. R.; Bonacin, J. A.; Toma, H. E. Spectrochim. Acta, Part A 2008, $71,1296$.

(47) (a) England, J.; Gondhia, R.; Bigorra-Lopez, L.; Petersen, A. R.; White, A. J. P.; Britovsek, G. J. P. Dalton Trans. 2009,
5319. (b) Li, F.; Wang, M.; Gao, A.; Chen, H.; Sun, L. Dalton Trans. 2006, 2427.

(48) (a) Stynes, D. V.; Noglik, H.; Thompson, D. W. Inorg. Chem. 1991, 30, 4567. (b) Weiss, H.; Strähle, J. Z. Naturforsch., B 1984, 39, 1453.

(49) (a) Bhadbhade, M. M.; Srinivas, D. Polyhedron 1998, 17, 2699. (b) Chen, K.; Costas, M.; Que, L. Jr. J. Chem. Soc., Dalton Trans. 2002, 672

(50) (a) Haselhorst, G.; Wieghardt, K.; Keller, S.; Schrader, B. Inorg. Chem. 1993, 32, 520. (b) James, M.; Kawaguchi, H.; Tatsumi, K. Polyhedron 1997, 16, 1873. (c) Cámpora, J.; Naz, A. M.; Palma, P.; Rodríguez-Delgado, A.; Álvarez, E.; Tritto, I.; Boggioni, L. Eur. J. Inorg. Chem. 2008, 1871.

(51) (a) Bart, S. C.; Chłopek, K.; Bill, E.; Bouwkamp, M. W.; Lobkovsky, E.; Neese, F.; Wieghardt, K.; Chirik, P. J. J. Am. Chem. Soc. 2006, 128, 13901. (b) Lu, C. C.; Bill, E.; Weyhermüller, T.; Bothe, E.; Wieghardt, K. J. Am. Chem. Soc. 2008, 130, 3181.

(52) Some of the isolated products contained small amounts $(\sim 5$ mol\%) of silyl impurities, as assessed by ${ }^{1} \mathrm{H}$ NMR spectroscopy. All ${ }^{13} \mathrm{C}\left\{{ }^{1} \mathrm{H}\right\}$ NMR spectra showed baseline purity.

(53) The syn/anti ratios were determined based on the ${ }^{3} J_{\mathrm{HH}}$ coupling constants of the $\mathrm{H}-\mathrm{C}-\mathrm{OSiR}_{3}$ proton (syn: $<1 \mathrm{~Hz}$, anti: 4.5 Hz); see: Bifulco, G.; Dambruoso, P.; GomezPaloma, L.; Riccio, R. Chem. Rev. 2007, 107, 3744.

(54) Lin, J.-M.; Liu, B.-S. Synth. Commun. 1997, 27, 739.

(55) de Nanteuil, G.; Waser, J. Angew. Chem. Int. Ed. 2011, 50, 12075.

(56) Bruker Analytical X-ray, Madison, Wisconsin (USA), 2010.

(57) Sheldrick, G. M. Acta Crystallogr., Sect. A 2008, 64, 112. 